\title{
Effects of Different Land-use Managements on Soil Fertility Status in Rift Valley Areas of Gamo-Konso Massifs, Ethiopia
}

\author{
*YADDA, TA; ZEBIRE, DA \\ Arba Minch University, College of Agricultural Sciences, Department of Plant Science, P. O. Box 21, Arba Minch, Ethiopia \\ *Corresponding Author Email: asefadegife@gmail.com
}

\begin{abstract}
S: Understanding soil properties and their productiveness under different land use management have proved to be useful for sustainable development and efficient utilization of limited land resources. A systematic soil survey was made for the first time in the Ethiopian Rift valley flat plain areas of Gamo-Konso Massifs. The objectives were to: (1) identify the land uses and their role on soil physicochemical properties under varying climatic conditions; (2) assess the nature and extent of soil salinity problems; (3) identify best land use management practices. Annual crops (AA); perennial crops (AP), and Natural Forest (NF) land-uses were identified. The result showed organic carbon (OC) and total nitrogen (TN) were varied along different land uses. Generally, OC, TN, percentage base saturation, exchangeable (potassium, calcium and magnesium), available, phosphorus $\left(\mathrm{P}_{2} \mathrm{O}_{5}\right)$, manganese, copper and iron contents decreased in cultivated areas. The AA has less nutrient content compared to AP in irrigated agriculture while in AP it is greater than AA under rainfed. Clay, TN, $\mathrm{P}_{2} \mathrm{O}_{5}$ and available potassium $\left(\mathrm{K}_{2} \mathrm{O}\right)$ contents were correlated positively and highly significantly with $\mathrm{OC}$ and electrical conductivity (EC). In conclusion, the study revealed that most of the soil properties are influenced by land use management. Therefore, it could be recommended to include management practices that increase $\mathrm{OC}$ and TN in the system, when the land is continuously cultivated. Reclamation of the areas should start by considering available options like crop rotation as a good means of management.
\end{abstract}

\section{DOI: https://dx.doi.org/10.4314/jasem.v23i8.21}

Copyright: Copyright (C) 2019 Yadda and Zebire. This is an open access article distributed under the Creative Commons Attribution License (CCL), which permits unrestricted use, distribution, and reproduction in any medium, provided the original work is properly cited.

Dates: Received: 12 July 2019; Revised: 18 August 2019; 29 August 2019

Keywords: Land use management, soil fertility soil nutrient, soil physicochemical properties.

Soil, land, water and forests are the foundations of Ethiopia's economic development, food security and livelihood sustenance. These issues face additional pressures through climate variability and stresses (FDRE, 2011). Understanding soil properties and their productiveness under different land use management have proved to be useful for sustainable development and efficient utilization of limited land resources (Buol et al., 2003). Likewise, the soil is an important nonrenewable land resource determining the agricultural potential of a given locality. In Southern Ethiopia, sustainable soil management practices that are based on the understanding of soil systems are not practiced effectively in most part of the area (Tuma, 2007). Also, the land-use pattern in the study area is substantially changed through time with the implementation of modern irrigation and subsequent infrastructure development such as road facility and emerging market-based economy system during the last few decades. Hence, there is a need to initiate a detailed soil productivity analysis in different parts of the country in relation to land management. There is a wide set of soil fertility issues that require approaches that go beyond the application of inorganic fertilizersthe only practice applied at large scale to date (IFPRI,
2010). Core constraints include depletion of organic matter due to the widespread use of biomass as fuel, depletion of macro and micro-nutrients, topsoil erosion, depletion of soil physical properties, and increased soil salinity. Regarding to inorganic fertilizer application (IFPRI, 2010), there are a set of value-chain constraints: (1) Chemical fertilizer faces limited reach of needy farmers where appropriate application can enhance yields; (2) Bio-fertilizer is constrained by low demand, due to lack of awareness and understanding of the product, and limited production capacity. Extensive testing to identify appropriate products is needed; however, research efforts are currently limited towards this end. In Ethiopia due to the belief that the soils are developed from K-rich parent material, attention is not given to potassium $(\mathrm{K})$ fertilization. It is only $\mathrm{P}$ and $\mathrm{N}$ fertilizers that are being used in the country. But the belief is based on the work done before $30-40$ years by Murphy (1968), which indicated that the K content of most Ethiopian soils is high. However, in current soil analysis availability of $\mathrm{K}$ in the soil is lowered. Moreover, the soil fertility interventions are constrained by lack of up-to-date data; these interventions depend on major national soil surveys 
dating to the 1980s (FAO) and macronutrient studies from the1950s-60s and inhibit adoption of these practices by smallholder farmers. Also, fertilizer application per hectare of land is not uniform, soil fertility status is not identified and productivity is lowered because of low fertilizer rate usage and other related factors in the study area. According to MoA (1995), the major indicators for the evaluation of potential soil fertility are (1) soil organic matter (SOM), (2) cation exchange capacity (CEC), (3) soil $\mathrm{pH}$, (4) soil texture, and (5) available phosphorus (Av.P). In addition, standard soil fertility attributes such as soil depth, soil $\mathrm{pH}, \mathrm{OC}, \mathrm{N}, \mathrm{P}$, and $\mathrm{K}$ are important parameters in terms of plant growth, crop production and microbial diversity and function (Doran and Parkin, 1994). SOM is a very important fraction of the soil because of its high CEC and retaining nutrients against leaching losses. Depending upon the parent material and extent of weathering, the TN (\%) content of soil all over the world ranges from 0.015 to 0.137 (Ramesh et al., 2007). All soils contain some water-soluble salts, but when these salts occur in amounts that are above required optimum level, they are harmful and toxic for plants; (Denise, 2003). The soluble salts that occur in soils consist of mostly various proportions of the cations $\mathrm{Ca}^{2+}, \mathrm{Mg}^{2+}$ and $\mathrm{Na}^{+}$, and the anions $\mathrm{Cl}^{-}$, and $\mathrm{SO}_{4}{ }^{2-}$. Constituents that ordinarily occur only in minor amounts are the cation $\mathrm{K}^{+}$and the anions $\mathrm{HCO}_{3}{ }^{-}, \mathrm{NO}_{3}{ }^{-}$and $\mathrm{CO}_{3}{ }^{2-}$ but soluble carbonates are almost invariably absent. Saline soils are often recognized by the presence of white crusts of salts on the soil surface called "White alkali" and irregular plant growth (Denise, 2003). Hence, land-use and type of vegetation must be taken into account when relating soil nutrients with environmental conditions (Ramesh et al., 2007), and in characterizing soil nutrients/soil nutrient stocks.

At present, about $80 \%$ of the study area is under cultivation (Tuma, 2007), it was found to be of paramount importance to study soil physicochemical properties, soil macro and micronutrients in relation to different land use systems in comparison with natural forest soils. The main objective of the current study was to assess the effect of different land uses management on soil fertility status in rift valley areas of Gama-Konso massifs, Ethiopia.

\section{MATERIALS AND METHODS}

Descriptions of the study area: The study area is located within the Abaya Chamo lakes basin. It comprises two watersheds Sille-Sego and ArgubaWezeka. The area lies in between 05 $39^{\prime} 36^{\prime \prime}$ and $05^{\circ} 54^{\prime} 2^{\prime \prime} \mathrm{N}$ and $37^{\circ} 24^{\prime} 36^{\prime \prime}$ to $37^{\circ} 30^{\prime} 2^{\prime \prime}$ E $\mathrm{E}$ at an altitude range of 1100 to 1280 masl. The pattern of the topography of the catchment is composed of flat plain in the west-around Lake Chamo and the Rift Valley escarpment hills in the west and north. The parent materials of the catchment are alluvium along the river and lacustrine along the lake that are derivatives from the rocks (GME, 1975; EMA, 1975).

According to the climatic data taken from 1992 to 2012 from the nearby meteorological stations (at Arba Minch and Gedole), the mean annual rainfall in the study area is $930 \mathrm{~mm}$. The rainfall season is from May to October and it has two peaks (May and August) with no distinct dry season between the two peaks. The mean annual temperature is $19.9^{\circ} \mathrm{C}$ and monthly values range between $17.7^{\circ} \mathrm{C}$ in July and $22.1^{\circ} \mathrm{C}$ in February and March. In general, the length of Growing Period (LGP) of Arba Minch area is 61 days (Lemma, 1996); this implies that evapotranspiration is by far greater than rainfall and the need to supplement irrigation water for growing of different crops is mandatory.

Primary Data Collection and Land Uses Classification: Semi-structured questionnaires were used to gather pertinent information on land uses, history of cultivation, cropping patterns, soil management practices, etc. In addition, observation, discussion and interview were made at each village level with seniors. Discussions were focused on overall performance, history of the respective land use systems. With respect to the farm level, five adjacently located farm owners were interviewed in order to know the farm history. A field survey was carried out to collect data on the current land use systems and the physiognomic vegetation classification system in accordance with FAO (1985, 1995 and 2006), and secondary data were collected from respective Kebele offices. The agro-ecological zonation attributes determine similarities, such as (1) comparable agroclimatic conditions for annual cropping, perennial cropping, or agroforestry, and (2) comparable land resource conditions such as soils or vegetation parameters (Hurni, 1999; Tuma, 2007).

Soil sampling and laboratory analysis: Surface soil samples were taken from $(0-20 \mathrm{~cm}$ depth) at randomly from 60 soils sampling sites and six composites were prepared from 60 samples following the standard procedures of composite soil sampling method. These samples were air dried and passed through 2-mm sieve for determination of physical and chemical characteristics in Water Works Design and Supervision Enterprise laboratory Service in 2012. Particle size analysis was carried out by the modified sedimentation hydrometer procedure (Bouyoucos, 1951). The $\mathrm{pH}$ of the soils was determined in $\mathrm{H}_{2} \mathrm{O}$ $\left(\mathrm{pH}-\mathrm{H}_{2} \mathrm{O}\right)$ and $1 \mathrm{M} \mathrm{KCl}(\mathrm{pH}-\mathrm{KCl})$ using 1:2.5 soil to 
solution ratio using $\mathrm{pH}$ meter as outlined by Van Reeuwijk (1993).

The organic carbon content of the soil was determined using the wet combustion method of Walkley and Black as outlined by Van Ranst et al. (1999). Soil TN was analyzed by the wet-oxidation procedure of the Kjeldahl method (Bremner and Mulvaney, 1982). The $\mathrm{P}_{2} \mathrm{O}_{5}$ contents of the soils were analyzed using the Olsen sodium bicarbonate extraction solution ( $\mathrm{pH} 8.5)$ method as outlined by Van Reeuwijk (1993) and the amount of $\mathrm{P}_{2} \mathrm{O}_{5}$ was determined by spectrophotometer at $882 \mathrm{~nm}$ and $\mathrm{K}_{2} \mathrm{O}$ (Jackson, 1967). The available $\mathrm{N}$ was estimated from OC content of the soils. Exchangeable basic cations and the cation exchange capacity (CEC) of the soils were determined by using the $1 \mathrm{M}$ ammonium acetate $(\mathrm{pH} 7)$ method according to the percolation tube procedure (Van Reeuwijk, 1993). The exchangeable $\mathrm{Ca}$ and $\mathrm{Mg}$ in the leachate were determined by Atomic Absorption Spectrophotometer (AAS), whereas exchangeable K and $\mathrm{Na}$ were measured by flame photometer. $\mathrm{CaCO}_{3}$ was determined by acid neutralization method using $\mathrm{HCl}$. Exchangeable cation was measured from a soil saturation extract by a conductivity meter. Available micronutrients $(\mathrm{Fe}, \mathrm{Mn}, \mathrm{Zn}$, and $\mathrm{Cu}$ ) contents of the soils were extracted by diethylene-triaminepentaacetic acid (DTPA) method (Tan, 1996) and the contents of available micronutrients in the extract were determined by AAs. The soil samples were processed and analyzed for all above-mentioned parameters.

Statistical Analysis: Randomized Complete Block Design (RCBD) was used for the selected soil physicochemical properties. Data analysis was carried using SAS 8.2 Version System (SAS, 2001) to compare the effects of different land uses on soils physicochemical properties.

\section{RESULTS AND DISCUSSION}

Land Use Systems in Lowland Areas of Gamo-Konso Massifs: The studied land use systems were generally found within slope range between almost flat (1\%) and slightly sloping (2\%). Smooth variation in elevation is suitable for surface irrigation with respectable to topography. Thus, the slope $<10 \%$ is considered to be a suitable range of slope classification for surface irrigation with minor adjustment to negotiate the natural slope. The soils of land uses were young and derived from alluvium deposits (Table 1). Mesfin (1998) has also indicated that flooding obstructs the pedogenic material. Generally, there is low runoff and good drainage in the study area soils (Table 1), probably due to the slope of the landscape position (Table 1) and depth of the soil (Table 2). In the escarpment between lowland catchment and highland areas, the scattered trees were cleared and replaced by the settlement of human population because of a shortage of farmland in the nearby highlands, absence of other livelihood alternatives to rural-urban migrants, and proliferating rural poverty and unemployment. Most of the researchers agree that the poor are victims of resource degradation, and the resource depletion and degradation become worse when it is open access to all with high demand. Apart from the deforested hilltops, the study area was remarkably well covered by recently introduced fruit trees. There was a breakthrough in the production and transforming the livelihoods of the inhabitants from a survival level to the elevated way of life at lowlands in the irrigated zone; fast changes are taking place now in farming systems, individual crops, peoples' lifestyles, breaking of traditional systems. For example, improved farming methods such as mulching, intercropping, and shifting cultivation were also well practiced. The cropping pattern of the area was substantially changed through time, particularly, the fruit crops' production was increased and fruits became the main plants growing in the irrigated area. As a result, the smallholders farming systems in the area are dominated by banana, mango and mixed farming system or agroforestry, and annual field cropping of maize, sorghum, cotton and other pulse crops in the rainfed agriculture. Moreover, vegetation in the lowland areas of Gamo-Konso Massifs is varying according to variability in rainfall, soil salinity and soil moisture contents (Table 2).

Table 1: Physiographic Characteristics of the lowland areas of Gamo-Konso Massifs, 2012

\begin{tabular}{|c|c|c|c|c|c|c|c|c|}
\hline Site & $\begin{array}{l}\text { Latitude } \\
\text { (N) }\end{array}$ & $\begin{array}{l}\text { Longitud } \\
\text { e (E) }\end{array}$ & $\begin{array}{l}\text { Altitude } \\
\text { (m.a.s.l. } \\
\text { ) }\end{array}$ & Physiography & PM & $\begin{array}{l}\text { Slope } \\
\text { (\%) }\end{array}$ & Drainage class & Erosion \\
\hline \multicolumn{9}{|c|}{ Sille-Sego Watershed = Supplementary Irrigated Agriculture } \\
\hline AA6-CeMa & $05^{0} 51 ’ 43^{\prime \prime}$ & $37^{0} 29 ' 50^{\prime \prime}$ & 1113 & Alluvial Mid Plain & Colluvium & 1 & Poor & None \\
\hline $\mathrm{AP} 2-\mathrm{FrBa}$ & $05^{0} 54^{\prime} 2^{\prime \prime}$ & $37^{0} 30^{\prime} 2^{\prime \prime}$ & 1100 & Alluvial Mid Plain & Colluvium & 1 & Poor & None \\
\hline FN1- FxTa & $05^{0} 43^{\prime} 01^{\prime \prime}$ & $37^{0} 24^{\prime} 36^{\prime \prime}$ & 1280 & Alluvial Mid Plain & Colluvium & 1 & Well-drained & None \\
\hline \multicolumn{9}{|c|}{ Arguba-Weseca Watershed = Conservation and Rainfed Agriculture } \\
\hline AA4-CeSo & $05^{0} 44^{\prime} 02^{\prime \prime}$ & $37^{0} 28^{\prime} 42^{\prime}$ & 1120 & Alluvial Plain & Alluvium & 1 & Well-drained & None \\
\hline AP1-MfMo & $05^{0} 43^{\prime} 26^{\prime \prime}$ & $37^{0} 25^{\prime} 46^{\prime \prime}$ & 1204 & Alluvial Mid Plain & Lacustrine & 1 & Well-drained & None \\
\hline PN1- FsSe & $05^{0} 39^{\prime} 36^{\prime \prime}$ & $37^{0} 27^{\prime} 02^{\prime \prime}$ & 1137 & Alluvial Plain & Alluvium & 2 & Well-drained & gully \\
\hline
\end{tabular}


Table 2. Vegetation and Land use classification in lowland areas of Gamo-Konso Massifs, CSB, 2012

\begin{tabular}{|c|c|c|}
\hline $\begin{array}{l}\text { Sampling } \\
\text { Sites }\end{array}$ & Plant species that indicate features of soil salinity under different LUTs & Land uses \\
\hline Mage -Mele & Sugar cane and Cotton, some salt tolerant tree species & AA6-CeMa \\
\hline $\begin{array}{l}\text { Sille/Ganta } \\
\text { Kenchema }\end{array}$ & $\begin{array}{l}\text { Musa sp, maginifera indica, Casuarina equisitifolia, Prosopis sp., Sesbania sp., } \\
\text { Moringa stenopetela }\end{array}$ & AP2-FrBa \\
\hline $\begin{array}{l}\text { Eligo } \\
\text { Bushland }\end{array}$ & $\begin{array}{l}\text { Tamarix Based Bushland: Tamarix sp. Salvadorapersica, Acacia longispinia or } \\
\text { Acacia tortolis and cyperus sp. }\end{array}$ & FN1-FxTa \\
\hline Walesa Fora & $\begin{array}{l}\text { Sorghum bicolor, perennial cotton, Phaseolus vulgaris L, Zea maize, Vigna } \\
\text { unguiculata, Targa SWC practices }\end{array}$ & AA4-CeSo \\
\hline $\begin{array}{l}\text { Walesa } \\
\text { Chara }\end{array}$ & $\begin{array}{l}\text { Moringa stenotepala, Dobera glabra, perennial cotton, Cajanus cajan,Vigna } \\
\text { unguiculata, Acacia alibida, Terminalia brownie, Digitaria diagonalis, Targa } \\
\text { SWC practices }\end{array}$ & AP1-MfMo \\
\hline Halite Forest & Sesbania spp, Acacia spp, Terminalia brownie & PN1-FsSe \\
\hline
\end{tabular}

The dominant land use systems are classified as annual farming of maize and/or sorghum system (AA), Perennial including Agroforestry Farming System (AP) and Representative Natural Forest and Woodland System (NF); and each of them was considered for this specific study (Table 2). Community categorize their farming system based on watercourse soil fertility status, viz.: cash crop farming (nearby watercourse); subsistence farming (midway watercourse); and mixed farming (at extreme distant to watercourse and moisture stress). Accordingly, the survey result from the Kebele has indicated that maize and banana fields were the dominant land use units in irrigated land uses, whereas subsistence and agroforestry farming systems were dominant in rain-fed agriculture. This is in agreement with Jarvis and Hodgkin (2000) that farmers shape the distribution and degree of diversity for the crops both directly through selection, and indirectly, through the management of biotic and abiotic agroecosystem components.

Soil Fertility Status in Lowland Areas of Gamo-Konso Massifs: Soil Organic Carbon (SOC) and Total Nitrogen (TN): Soil organic matter (SOM) values of surface soils varied from 1.28 to $4.67 \%$ (Table 4 ) along land uses, and SOM was low in agricultural fields. The SOM content of rainfed agricultural land uses was low for AA4-CeSo and AP1-MfMo whereas medium for all irrigated land uses. This indicates that for both irrigated and rainfed land uses, without application of nitrogen-containing fertilizers no adequate yields can be achieved.

We observed that specialized indigenous soil and water conservation practices used by Dherashe people locally called "Targa" was practised for many years up until now. The practice allows the permanent return of crop residuals into the soils systems of AA4-CeSo soils had the potential to sequester carbon compared to AP1-MfMo system in the soils. 'Targa' is a physical soil and water conservation method like terracing in Konso area, whereby stalk of sorghum, maize and other stalk bearing crops are piled in rows and placed at intervals of two to three meters and utilized as an organic fertilizer (humus). Organomineral complexes can also be formed with ions, particularly metallic ions such as $\mathrm{Fe}^{2+}, \mathrm{Cu}^{2+}, \mathrm{Zn}^{2+}$, and $\mathrm{Mn}^{2+}$, which will make them more available for plant uptake than in the mineral form (Table 4). The TN content of the surface soils ranged from 0.05 in AP1-MfMo to $0.33 \%$ in PNFsSe. The TN content of the surface soils is categorized from low to medium except for PN-FsSe, which was at high range. Accordingly, the TN content of soils are categorized as low $(<0.15)$, medium $(0.15$ - 0.25) and high (>0.25) (Table 4, Havlin et al., 1999). The difference in OC and TN content among the land uses could be attributed to the effect of variation in land use management along the watersheds. The distribution pattern of TN across land uses was similar to that of SOM, since SOM contents is a good indicator of available nitrogen status in the soil. Intensive and continuous cultivation aggravated OC oxidation, resulted in a reduction of $\mathrm{TN}$ as compared to PN-FsSel. The results are in accordance with the findings of Tuma (2007) who reported that intensive and continuous cultivation forced oxidation of $\mathrm{OC}$ and thus resulted in a reduction of $\mathrm{TN}$.

Available phosphorus $\left(\mathrm{P}_{2} \mathrm{O}_{5}\right)$ in Soils: The $\mathrm{P}_{2} \mathrm{O}_{5}$ contents of the surface soils is an essential element for plant growth; hence it is an important soil fertility indicator. The $\mathrm{P}_{2} \mathrm{O}_{5}$ content of the surface soils is very high, and it ranged from 39.28 to $251.34 \mathrm{mg} / \mathrm{kg}$ with a mean value of $117.40 \mathrm{mg} / \mathrm{Kg}$ (Table 3 ), which is in a very high range for all land units. The available Olsen $\mathrm{P}_{2} \mathrm{O}_{5}(\mathrm{mg} / \mathrm{kg})$ contents of the soils rated as very low $(<5)$, low (5-9), medium (10-17), high (18- 25) and very high (>25) (Table 4; Havlin et al., 1999). The highest concentration of $\mathrm{P}_{2} \mathrm{O}_{5}$ under the PN1-FsSe is attributed to the accumulation of SOM due to little soil disturbance as compared to the AA4-CeSo. Higher $\mathrm{P}_{2} \mathrm{O}_{5}$ values in the surface horizon could be attributed to the difference in SOM contents, the difference in land use management and the neutral and near neutral range soil $\mathrm{pH}$. In most soils, there is an increase in $\mathrm{P}_{2} \mathrm{O}_{5}$ after flooding, due to increased solubility of $\mathrm{Ca}$ 
phosphate in calcareous soils, and greater diffusion (Havlin et al., 1999). The high and positive correlation $\left(\mathrm{r}=0.91^{* *}\right)$ obtained between $\mathrm{TN}, \mathrm{OC}$ and $\mathrm{P}_{2} \mathrm{O}_{5}$ (Table 4) indicates SOM highly contributes to $\mathrm{P}_{2} \mathrm{O}_{5}$ of soils. Based on the above results it is not compulsory to apply $\mathrm{P}_{2} \mathrm{O}_{5}$ in all the land use systems studied. The $\mathrm{C}$ : $\mathrm{N}$ ratio of surface soils ranged from 7.95 to 15.59 suggesting that the studied soils had a moderate to good quality SOM (Table 4). It is generally accepted that $\mathrm{C}: \mathrm{N}$ ratios between 8 and 12 are considered to be the most favourable, implying relatively fast mineralization of nitrogen from the organic materials. Generally, the observed C: $\mathrm{N}$ ratio status in surveyed sites suggests ideal conditions for plant growth, however, the lower the $\mathrm{C}: \mathrm{N}$ ratio is because of the lower the OC and TN in some studied sites.

Table 3 Physicochemical properties of soils in the Gamo-Konso Massifs, CSB, 2012

\begin{tabular}{|c|c|c|c|c|c|c|c|c|c|c|c|}
\hline \multirow{2}{*}{$\begin{array}{l}\text { Managem } \\
\text { ent }\end{array}$} & \multirow[t]{2}{*}{ Land uses } & \multicolumn{6}{|c|}{ Major Plant Nutrients- Micronutrients } & \multicolumn{4}{|c|}{ Available Micronutrients } \\
\hline & & $\mathrm{OC}$ & SOM & $\mathrm{TN}$ & C: $\mathrm{N}$ & $\mathrm{P}_{2} \mathrm{O}_{5}$ & $\mathrm{~K}_{2} \mathrm{O}$ & $\mathrm{Cu}$ & $\mathrm{Fe}$ & $\mathrm{Mn}$ & $\mathrm{Zn}$ \\
\hline \multirow[t]{3}{*}{ Irrigated } & AA6-CeMa & 1.79 & 3.10 & 0.15 & 11.96 & 124.40 & 226.44 & 1.06 & 13.20 & 3.10 & 1.06 \\
\hline & AP2-FrBa & 2.33 & 4.10 & 0.23 & 10.02 & 138.04 & 320.14 & 1.04 & 19.07 & 3.01 & 1.20 \\
\hline & FN1- FxTa & 1.80 & 3.11 & 0.12 & 15.59 & 96.76 & 391.96 & 1.05 & 16.31 & 13.09 & 0.84 \\
\hline \multirow{3}{*}{ Rianfed } & AA4-CeSo & 0.93 & 1.62 & 0.12 & 7.95 & 39.82 & 546.59 & 1.75 & 13.69 & 13.03 & 0.96 \\
\hline & AP1-MfMo & 0.74 & 1.28 & 0.05 & 14.90 & 54.60 & 190.82 & 0.79 & 12.11 & 4.33 & 0.79 \\
\hline & PN1- FsSe & 2.70 & 4.67 & 0.33 & 8.11 & 251.34 & 216.03 & 1.89 & 40.25 & 28.89 & 3.16 \\
\hline
\end{tabular}

Table 4: Simple correlation of surface soil $(0-20 \mathrm{~cm})$ between land use and soil properties

\begin{tabular}{|c|c|c|c|c|c|c|c|c|c|c|c|c|c|c|c|c|c|c|c|c|c|c|}
\hline & $\mathrm{Fe}$ & $\mathrm{Mn}$ & $\mathrm{Zn}$ & $\mathrm{Cu}$ & Ec & Silt & Clay & $\mathrm{Na}$ & $\mathrm{K}$ & $\mathrm{Ca}$ & $\mathrm{Mg}$ & CEC & |PBS & TN & $\mathrm{OC}$ & AP & AK & $\mathrm{CaCO} 3$ & $\mathrm{PH}(\mathrm{H} 2 \mathrm{O})$ & $\mathrm{PH}(\mathrm{KCl})$ & Cations & \begin{tabular}{|l|} 
Anions \\
\end{tabular} \\
\hline $\mathrm{Fe}$ & & \begin{tabular}{|l|} 
\\
\end{tabular} & \begin{tabular}{|l|}
0.69 \\
\end{tabular} & 0.05 & -0.3 & \begin{tabular}{|l|}
$\mid-0.83$ \\
\end{tabular} & \begin{tabular}{|l|} 
\\
\end{tabular} & -0.15 & -0.09 & $\mid-0.11$ & 0.15 & 0.54 & -0.54 & $0.90^{*}$ & $0.76^{*}$ & $0.92 *$ & $\begin{array}{l}-0.3 \\
\end{array}$ & \begin{tabular}{|l|} 
\\
0.58
\end{tabular} & -0.42 & -0.42 & \begin{tabular}{|l|}
-0.02 \\
\end{tabular} & -0.04 \\
\hline $\mathrm{Mn}$ & & & -0.62 & 0.49 & 0.06 & -0.48 & 0.53 & 0.03 & 0.05 & \begin{tabular}{|c|}
-0.16 \\
\end{tabular} & 0.22 & 0.24 & -0.24 & \begin{tabular}{|l|} 
\\
\end{tabular} & 0.83 & \begin{tabular}{|l|} 
\\
\end{tabular} & 0.85 & -0.37 & 0.45 & 0.37 & \begin{tabular}{l|l|}
0.02 \\
\end{tabular} & \begin{tabular}{|c|}
0.03 \\
\end{tabular} \\
\hline $\mathrm{Zn}$ & & & & 0.52 & 0.12 & 0.02 & -0.12 & 0.29 & 0.42 & \begin{tabular}{|l|}
-0.28 \\
\end{tabular} & 0.21 & 0.05 & -0.21 & \begin{tabular}{|l|}
0.68 \\
\end{tabular} & 0.69 & 0.69 & -0.19 & 0.32 & \begin{tabular}{|c|}
-0.49 \\
\end{tabular} & -0.41 & -0.32 & -0.31 \\
\hline $\mathrm{Cu}$ & & & & & 0.1 & -0.18 & 0.28 & -0.03 & 0.95 & \begin{tabular}{|c|}
-0.87 \\
\end{tabular} & -0.46 & -0.34 & \begin{tabular}{|c|} 
\\
\end{tabular} & 0.03 & 0.2 & -0.26 & 0.86 & $\begin{array}{l}-0.67 \\
\end{array}$ & \begin{tabular}{|c|}
-0.37 \\
\end{tabular} & -0.39 & -0.52 & $\begin{array}{l}-0.55 \\
\end{array}$ \\
\hline$\overline{E c}$ & & & & & & 0.08 & -0.14 & 0.5 & -0.22 & 0.34 & -0.93 & -0.55 & -0.23 & \begin{tabular}{|l|} 
\\
\end{tabular} & 0.1 & 0.01 & $\begin{array}{l}-0.17 \\
\end{array}$ & 0.05 & $\begin{array}{l}0.07 \\
\end{array}$ & -0.02 & 0.78 & 0.79 \\
\hline Silt & & & & & & & -0.84 & \begin{tabular}{|l|}
-0.29 \\
\end{tabular} & -0.42 & 0.52 & -0.28 & -0.25 & -0.55 & 0.15 & -0.04 & -0.13 & -0.22 & -0.18 & 0.5 & 0.54 & 0.16 & 0.2 \\
\hline \begin{tabular}{|l|} 
Clay \\
\end{tabular} & & & & & & & & 0.29 & -0.95 & \begin{tabular}{|c|}
-0.66 \\
\end{tabular} & 0.28 & -0.25 & -0.55 & 0.15 & 0.04 & -0.14 & 0.87 & -0.45 & \begin{tabular}{l|l|}
-0.19 \\
\end{tabular} & -0.22 & -0.35 & \begin{tabular}{|c|}
-0.34 \\
\end{tabular} \\
\hline $\mathrm{Na}$ & & & & & & & & 1 & \begin{tabular}{c|}
-0.4 \\
\end{tabular} & 0.68 & -0.83 & -0.15 & \begin{tabular}{|l|}
0.55 \\
\end{tabular} & 0.06 & 0.43 & 0.22 & -0.34 & 0.44 & 0.32 & 0.28 & 0.71 & 0.72 \\
\hline $\mathrm{K}$ & & & & & & & & & 1 & -0.7 & 0.5 & \begin{tabular}{l|l|}
-0.12 \\
\end{tabular} & -0.54 & \begin{tabular}{|l|} 
\\
\end{tabular} & -0.14 & -0.3 & $0.96 * *$ & -0.5 & \begin{tabular}{|c|}
-0.08 \\
\end{tabular} & -0.1 & \begin{tabular}{c|c|}
-0.51 \\
\end{tabular} & \begin{tabular}{|l|}
-0.55 \\
\end{tabular} \\
\hline $\mathrm{Ca}$ & & & & & & & & & & & -0.55 & 0.41 & 0.81 & 0.01 & 0.25 & 0.12 & -0.54 & 0.73 & 0.71 & 0.71 & 0.62 & 0.62 \\
\hline $\mathrm{Mg}$ & & & & & & & & & & & 1 & 0.33 & \begin{tabular}{l|l|}
-0.3 \\
\end{tabular} & 0.15 & -0.15 & \begin{tabular}{|c|} 
\\
\end{tabular} & 0.42 & -0.31 & \begin{tabular}{|c|}
-0.17 \\
\end{tabular} & -0.07 & -0.94 & -0.96 \\
\hline $\mathrm{CEc}$ & & & & & & & & & & & & ${ }^{\prime}$ & \begin{tabular}{|c|}
0.11 \\
\end{tabular} & 0.43 & 0.47 & 0.42 & -0.11 & 0.76 & 0.45 & 0.49 & -0.08 & \begin{tabular}{|l|}
-0.12 \\
\end{tabular} \\
\hline PBs & & & & & & & & & & & & & 1 & \begin{tabular}{l|l|}
-0.4 \\
\end{tabular} & -0.1 & -0.29 & $\begin{array}{l}-0.35 \\
\end{array}$ & 0.27 & $\begin{array}{l}0.68 \\
\end{array}$ & 0.74 & 0.23 & \begin{tabular}{|l|}
0.26 \\
\end{tabular} \\
\hline TN & & & & & & & & & & & & & & & $0.91 * *$ & \begin{tabular}{|l|}
0.93 \\
\end{tabular} & -0.21 & 0.52 & \begin{tabular}{|c|}
-0.43 \\
\end{tabular} & -0.4 & \begin{tabular}{|c|}
-0.13 \\
\end{tabular} & \begin{tabular}{|l|}
-0.15 \\
\end{tabular} \\
\hline $\mathrm{OC}$ & & & & & & & & & & & & & & & & 0.91 & -0.3 & 0.73 & -0.13 & -0.11 & \begin{tabular}{l|l}
0.17 \\
\end{tabular} & \begin{tabular}{|l|}
0.15 \\
\end{tabular} \\
\hline $\mathrm{AP}$ & & & & & & & & & & & & & & & & 1 & -0.5 & 0.68 & \begin{tabular}{|c|}
-0.38 \\
\end{tabular} & -0.38 & 0.17 & 0.17 \\
\hline$\widehat{\mathrm{AK}}$ & & & & & & & & & & & & & & & & & 1 & -0.5 & 0.16 & 0.13 & \begin{tabular}{l|l|}
-0.4 \\
\end{tabular} & \begin{tabular}{|l|}
-0.45 \\
\end{tabular} \\
\hline $\mathrm{CaCO} 3$ & & & & & & & & & & & & & & & & & & & 0.39 & 0.38 & 0.48 & 0.46 \\
\hline $\mathrm{pH}(\mathrm{H} 2 \mathrm{O})$ & & & & & & & & & & & & & & & & & & & & $0.99 * * *$ & $\begin{array}{l}0.3 \\
\end{array}$ & 0.27 \\
\hline $\mathrm{pH}(\mathrm{KCl})$ & & & & & & & & & & & & & & & & & & & & & 0.19 & 0.16 \\
\hline Cations & & & & & & & & & & & & & & & & & & & & & 1 & 0.99 \\
\hline Anions & & & & & & & & & & & & & & & & & & & & & & 1 \\
\hline
\end{tabular}

Available potassium $\left(\mathrm{K}_{2} \mathrm{O}\right)$ in Soils: In the studied areas, the $\mathrm{K}_{2} \mathrm{O}$ content of the surface soils was ranged from 190.82 to $546.59 \mathrm{mg} / \mathrm{kg}$ of soil with a mean value of $315.33 \mathrm{mg} / \mathrm{kg}$, which is in a very high range. Generally, $\mathrm{K}_{2} \mathrm{O}_{5}$ rated as very low $(<120)$, low $(121$ 240), medium (241-300), high (300-360) and very high (>360) (Table 3; Tandon, 2005). The positive and high correlation $\left(\mathrm{r}=0.87^{*}\right)$ obtained between clay and $\mathrm{K}_{2} \mathrm{O}$ indicates the prevalence of a potassium-rich clay mineral (Illite) in these soils that highly contributes to $\mathrm{K}_{2} \mathrm{O}$ of soils, which is in agreement with Kanwar (1959). Since the very high CEC values ranged from 33.84 to $39.44 \mathrm{cmol} \mathrm{(+)} \mathrm{\textrm {kg } ^ { - 1 }}$ in the studied soils, it is generally indicating the presence of Illite (micas) clay minerals in the soils. Bierman and Rosen (2005) as indicated that cation exchange is the major nutrient reservoirs of $\mathrm{K}^{+}, \mathrm{Ca}^{2+}$ and is also important in holding $\mathrm{N}$ in ammonium $\left(\mathrm{NH}^{+}\right)$form. The positive and very high correlation $\left(\mathrm{r}=0.96^{* * *}\right)$ obtained between exchangeable $\mathrm{K}$ and $\mathrm{K}_{2} \mathrm{O}$ (Table 4) indicates exchangeable $\mathrm{K}$ highly contributes to $\mathrm{K}_{2} \mathrm{O}$ of soils. Vegetation restoration increases the accumulation of soil $\mathrm{K}$ because the nutrient-rich branches and coarse litter fraction are all-important nutrient sources.

Micronutriments (Fe, Mn, Zn, Cu) in Soils: The concentration of available micronutrients in studied soils were found to be $\mathrm{Fe}>\mathrm{Mn}>\mathrm{Cu}>\mathrm{Zn}$ in almost all surface soils. This is in agreement with various works which stated that $\mathrm{Zn}$ contents are variable and, Fe and Mn contents usually at an adequate level in Ethiopian soils (Desta, 1982; Fisseha, 1992; Abayneh, 2005; Tuma, 2007). Concentrations of $\mathrm{Fe}, \mathrm{Cu}$ and $\mathrm{Zn}$ of surface soils are negatively correlated with soil $\mathrm{pH}$ (Table 4). The solubility and availability of micronutrients are largely influenced by clay content, 
$\mathrm{pH}, \mathrm{SOM}, \mathrm{CEC}$, the phosphorus level in the soil and tillage practices (Fisseha, 1992). $\mathrm{Cu}$ in the soil is adsorbed on clays and oxides that complexed with $\mathrm{SOM}$, thus inducing its retention and immediate unavailability for the plant (Tuma, 2007). The authors have demonstrated that organically enriched surface soils contain a higher concentration of $\mathrm{Cu}$ than the subsurface soils. For example, $\mathrm{Fe}\left(\mathrm{r}=-0.83^{*}\right)$ was negatively and significantly correlated with silt indicated that the availability Fe decreased as silt content increases in the soil. Dissimilar results were reported by Sharma et al. (1996) who found a positive correlation between $\mathrm{Fe}$ and silt. Moreover, the $\mathrm{Fe}(\mathrm{r}=$ $\left.0.76^{*}, 0.90^{*}, 0.92^{* *}\right)$ was positively and significantly correlated with $\mathrm{OC}, \mathrm{TN}$ and $\mathrm{AP}$, respectively that the availability $\mathrm{Fe}$ increased as $\mathrm{OC}, \mathrm{TN}$ and $\mathrm{AP}$ content increase in the soil. TN and AP contents correlated positively and highly significantly $\left(\mathrm{r}=0.91^{* *}\right)$ with OC. The availability of micronutrients increased with
OM content might be ascribed to greater availability of chelating agents through OM. These results are in agreement with Yadav (2011) and Khalifa et al. (1996).

Exchangeable Bases ( $\mathrm{K}, \mathrm{Ca}, \mathrm{Mg}$ ): Exchangeable $\mathrm{K}^{+}$ levels ranged from $0.35-1.37 \mathrm{cmol} \mathrm{kg-1}$ in the soil (Table 5). Exchangeable $\mathrm{K}^{+}$in the soils rated as very low $(<0.2)$, low (0.2- 0.3), medium (0.35-0.6), high $(0.6-1.2)$ and very high $(>1.2)(\mathrm{FAO}, 2006)$ that for most of the crops, the recommended threshold level of $\mathrm{K}^{+}$is $0.3-0.6 \mathrm{cmol}(+) \mathrm{kg}^{-1}$. This result generally suggests that $\mathrm{K}^{+}$is not a limiting mineral element to crop productivity except in AP1-MfMo site. Since it is generally accepted that response to $\mathrm{K}$ fertilizers is likely when soil has an exchangeable $\mathrm{K}$ value of $<0.2$ cmol $(+) \mathrm{kg}^{-1}$ soil and unlikely when it is above 0.4 cmol (+) $\mathrm{kg}^{-1}$ soil (Table 5).

Table 5. Exchangeable and soluble Cations of soils in the Gamo-Konso Massifs, CSB, 2012

\begin{tabular}{|c|c|c|c|c|c|c|c|c|c|c|c|c|c|c|}
\hline \multirow{2}{*}{$\begin{array}{c}\text { Managem } \\
\text { ent }\end{array}$} & \multirow{2}{*}{$\begin{array}{c}\text { Land use } \\
\text { unit }\end{array}$} & \multicolumn{8}{|c|}{ Exchangeable bases } & \multicolumn{5}{|c|}{ Soluble Cations (meq/l) } \\
\hline & & $\mathrm{Na}$ & $\mathrm{K}$ & $\mathrm{Ca}$ & $\mathrm{Mg}$ & Sum & CEC & PBS & ESP & $\mathrm{Na}$ & $\mathrm{K}$ & $\mathrm{Ca}$ & $\mathrm{Mg}$ & sum \\
\hline \multirow[t]{3}{*}{ Irrigated } & AA6-CeMa & 1.13 & 0.55 & 26.35 & 3.02 & 31.05 & 33.81 & 91.84 & 3.33 & 0.67 & 0.37 & 0.80 & 0.40 & 2.25 \\
\hline & AP2-FrBa & 0.91 & 0.78 & 28.08 & 8.21 & 37.98 & 39.44 & 96.29 & 2.31 & 0.94 & 1.62 & 1.60 & 0.60 & 4.76 \\
\hline & FN1- FxTa & 1.00 & 0.82 & 29.96 & 4.82 & 36.06 & 39.08 & 92.27 & 2.55 & 2.24 & 0.41 & 1.60 & 1.00 & 5.24 \\
\hline \multirow[t]{3}{*}{ Rianfed } & AA4-CeSo & 0.53 & 1.37 & 18.58 & 9.07 & 29.55 & 35.69 & 82.80 & 1.47 & 1.37 & 0.30 & 1.40 & 0.40 & 3.47 \\
\hline & AP1-MfMo & 0.67 & 0.35 & 27.82 & 6.85 & 35.68 & 37.68 & 94.70 & 1.78 & 0.50 & 0.18 & 0.80 & 0.40 & 1.88 \\
\hline & PN1- FsSe & 0.72 & 0.65 & 24.19 & 6.91 & 32.48 & 39.44 & 82.33 & 1.83 & 0.44 & 0.74 & 1.80 & 0.60 & 3.59 \\
\hline
\end{tabular}

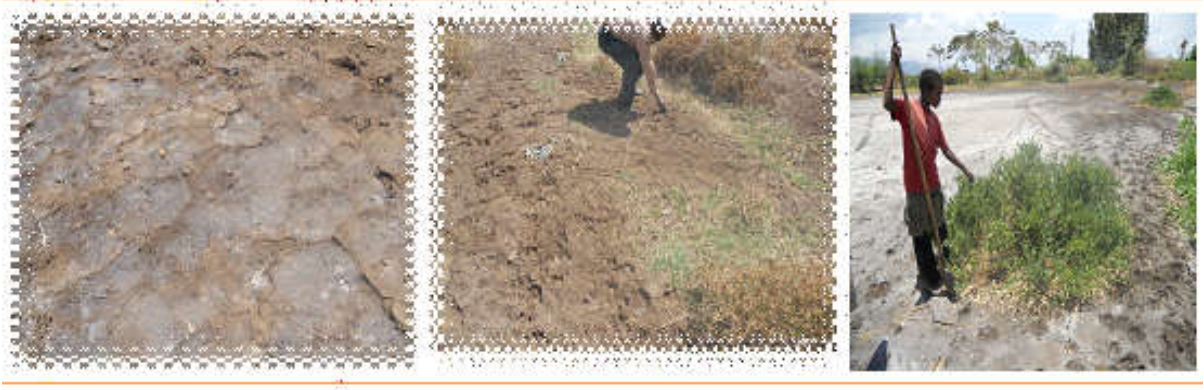

Fig 1: Whitish surface crust in the bare spots prevents the growth of even salt-tolerant plants.

Exchangeable $\mathrm{Ca}^{2+}$ in the surface soils of the studied land uses were ranged from $18.58-29.96 \mathrm{cmol}(+) \mathrm{kg}^{-}$ ${ }^{1}$ i.e., all studied land uses were rated as high to very high (Tables 4). For most of the crops, the recommended threshold level of $\mathrm{Ca}^{2+}$ is $5-10 \mathrm{cmol}(+)$ $\mathrm{kg}^{-1}$. The high to very high levels of $\mathrm{Ca}^{2+}$ in all studied soils indicate lower bondage of $\mathrm{Ca}^{2+}$ to Phosphorus (Table 4). Similarly, $\mathrm{Mg}^{2+}$ content was high to very high in all soils with values ranging from 3.02$9.07 \mathrm{cmol}^{(+)} \mathrm{kg}^{-1}$ (Table 4). For most of the crops, the recommended threshold level of $\mathrm{Mg}^{2+}$ is $1.0-3.0 \mathrm{cmol}$ (+) $\mathrm{kg}^{-1}$. The high to very high levels of $\mathrm{Mg}^{2+}$ in the soils suggest that the soils have sufficient natural $\mathrm{Mg}^{2+}$ supplies for crop growth in the studied sites. The exchange complex of the soils is dominated by $\mathrm{Ca}$ followed by $\mathrm{Mg}, \mathrm{K}$ and $\mathrm{Na}$ (Table 5). This result is in agreement with Tuma (2007) findings on fluvial soils in Gamo Gofa zone, Ethiopia, that Ca followed by $\mathrm{Mg}$, $\mathrm{K}$, and $\mathrm{Na}$ in the exchange site of soils are favorable for crop production. Though different crops have different optimum ranges of nutrient requirements, the response to calcium fertilizer was expected from most crops when the exchangeable calcium is less than 0.2 cmol (+) $\mathrm{kg}^{-1}$ of soil, while $0.5 \mathrm{cmol}(+) \mathrm{kg}^{-1}$ of soil was the deficiency threshold level in the tropics for $\mathrm{Mg}$ (Landon, 1991). For most surface soils the $\left(\mathrm{Ca}^{2+}+\mathrm{Mg} 2^{+}\right) /\left(\mathrm{Na}^{+}+\mathrm{K}^{+}\right)$ratios was in between 1 and 4 except for AP2-FrBa and FN1- FxTa, and the $\mathrm{Ca}^{++} / \mathrm{Mg}^{++}$-ratios are $\geq 1$ and varied from 2.0- 3.5 for all land uses (Table 5). It is believed that these soils are dominated by $\mathrm{Ca}$ and $\mathrm{Mg}$ over $\mathrm{Na}$ and $\mathrm{K}$ and remained stable structure even when the salts are flushed out of the 
soils, for example in land uses (AA6-CeMa and FN1FxTa) (Figure 1). Therefore, these soils are characterized as calcium-dominated saline soils (FAO, 2001). Notably, the anions are equally important in affecting the growth potential of the plants if they are in the order of importance $\mathrm{HCO}_{3}{ }^{-}+\mathrm{CO}_{3}{ }^{2-}>\mathrm{SO}_{4}{ }^{2-}>\mathrm{Cl}^{-}(\mathrm{FAO}, 2001)$.

Cationic balances: The cation exchange capacity (CEC) status in the soil ranged from $33.81-39.44 \mathrm{cmol}$ (+) kg-1 was rated as high (Table 5; Landon, 1991). The higher the CEC, the more capable the soil can retain mineral elements. It is generally accepted that SOM is responsible for $25-90 \%$ of the total CEC of surface mineral soils (Oades et al., 1989). The high CEC values in surface soils have also been implicated with high yield in most agricultural soils and CEC values in excess of $10 \mathrm{cmol} \mathrm{kg}^{-1}$ are considered satisfactory for most crops (FAO/IIASA/ISRIC/ISS-
CAS/JRC, 2012), and the clay content, the clay type and the OM content all determine the total nutrient storage capacity. Percent base saturation (PBS) of the soils ranged from 82.33 (PN1-FsSe) to 96.29 (AP2$\mathrm{FrBa}$ ), which indicates high fertility of the soil. Soils with high PBS are considered more fertile because many of the "bases" that contribute to it are plant nutrients. A positive and strong correlation $\left(r=0.68^{*}\right.$ and $\mathrm{r}=0.74^{*}$ ) correlation was found between PBS and $\mathrm{pH}-\mathrm{H}_{2} \mathrm{O}$ and $\mathrm{pH}-\mathrm{KCl}$ (Table 4) indicating that the strong association of $\mathrm{PBS}$ with $\mathrm{pH}-\mathrm{H}_{2} \mathrm{O}$ and $\mathrm{pH}-\mathrm{KCl}$, respectively. Our results have indicated K: CEC ratios in AP1-MfMo to be less than the suggested guidelines and plants would probably respond to the addition of $\mathrm{K}_{2} \mathrm{O}$ fertilizer (Table 6). This disproves the generally believe that Ethiopian soils are rich in $\mathrm{K}_{2} \mathrm{O}$ thus, requires further consideration in $\mathrm{K}_{2} \mathrm{O}$ fertilization.

Table 6. The basic cation saturation ratio and their relative proportions in the surface soils of the land-use units in the Gamo-Konso Massifs, CSB, 2012.

\begin{tabular}{|c|c|c|c|c|c|c|c|c|c|c|c|}
\hline \multirow[t]{2}{*}{ Mgt } & \multirow{2}{*}{$\begin{array}{l}\text { Land Use } \\
\text { unit }\end{array}$} & \multicolumn{2}{|c|}{$\mathrm{Ca} / \mathrm{CEC}$} & \multicolumn{2}{|c|}{ Mg/CEC } & \multicolumn{2}{|c|}{ K/CEC } & \multicolumn{2}{|c|}{$\mathrm{Ca} / \mathrm{Mg}$} & \multicolumn{2}{|c|}{$(\mathrm{Ca}+\mathrm{Mg}) / \mathrm{K}$} \\
\hline & & & Status & & Status & & Status & & Status & & tus \\
\hline \multirow[t]{3}{*}{ Irrigated } & AA6-CeMa & 0.78 & Adequate & 0.09 & Adequate & 0.02 & Adequate & 8.73 & proportional & 53.40 & Low K \\
\hline & AP2-FrBa & 0.71 & Adequate & 0.21 & Adequate & 0.02 & Adequate & 3.42 & proportional & 46.53 & Low $\mathrm{K}$ \\
\hline & FN1-FxTa & 0.77 & Adequate & 0.11 & Adequate & 0.02 & Adequate & 7.00 & proportional & 41.76 & Low $\mathrm{K}$ \\
\hline \multirow[t]{3}{*}{ Rainfed } & AA4-CeSo & 0.52 & Adequate & 0.25 & Adequate & 0.04 & Adequate & 2.05 & proportional & 20.18 & Med. K \\
\hline & AP1-MfMo & 0.74 & Adequate & 0.18 & Adequate & 0.01 & Low & 4.08 & proportional & 99.00 & Low $\mathrm{K}$ \\
\hline & PN1-FsSe & 0.61 & Adequate & 0.18 & Adequate & 0.02 & Adequate & 3.50 & proportional & 47.85 & Low $\mathrm{K}$ \\
\hline
\end{tabular}

The description was based on FAO (2001), Lecture notes on the major soils of the world, world Resources Reports \# 94, FAO, Rome

Conclusion: the study revealed that most of the soil properties are influenced by land use management. Therefore, it could be recommended to include management practices that increase $\mathrm{OC}$ and $\mathrm{TN}$ in the system, when the land is continuously cultivated. Therefore, reclamation of the areas should start by considering available options like crop rotation as a good means of management. Use of leguminous species that add $\mathrm{N}$ to the system are appropriate, however, nutrient flows and soil-plant analysis are required to give a concrete recommendation. Nutrients concentrations for most of the soil properties in the study showed that AP $>$ AA systems in irrigated soils while in rainfed soils AA $>$ AP. AP system improves soil productivity provided that nutrients are not removed from the system, because of the long fallow period and reestablishment of deep-rooted perennial plants.

Acknowledgements: The financial support from the Directorate office of Research, Arba Minch University to undertake this research endeavor is thankfully acknowledged. We extend our deepest gratitude to Dr Kassa Tekle for his critical suggestions and invaluable support.

\section{REFERENCES}

Abayneh, E (2005). Characteristics, genesis and classification of reddish soils from Sidamo Ethiopia. Ph.D thesis, University of Putra Malaysia. pp: 25-52.

Anderson, GD (1973). Potassium responses of various crops in East Africa. In: Proceedings of the 10th Colloquium of the International Potash Potash Insititute, Abijan, Ivory Coast. International Potash Insititute, Abijan. pp. 413 - 437.

Bandel, VA and Meisinger, JJ (2002). Basic principles of soil fertility II: Soil properties. College of Agriculture and Natural Resources. University of Mary land. FS- 640.

Bouyoucos, GJ (1951). A re-calibration of the hydrometer methods for making mechanical analysis of soils. Agron. J., 43: 434-438

Bremner, JM, Mulvaney, CS (1982). Nitrogen - total. In Page et al. (ed.) Methods of soil analysis. Chemical and microbiological properties. SSSA, Madison, Wisconsin. 2: 595-642 
Buol, SW; Southard, RJ; Grahm, RC; Daniel, PA (2003). Soil genesis and Classification.5th ed. Iowa State University Press. Ames, USA. pp. 550555

Desta, B (1982). Micronutrient status of some Ethiopian soils. Institute of Agricultural Research, Addis Ababa, Ethiopia. Soil Soc. Sci. p. 4.

Denise, MW (2003). Soil salinity and sodicity limits efficient plant growth and wateruse, Rio Grande Regional Soil and Water Series Guide A- 140, New Mexico State University, New Mexico.

Doran, JW and Parkin, TB (1994). Definition and assessing soil quality in: Soil SSSA. Special Publication No. 35. Madison.Vuisconsin.USA. $21 \mathrm{p}$.

EMA (Ethiopian Mapping Authority) (1975). National Atlas of Ethiopia, Addis Ababa, Ethiopia.

FAO/IIASA/ISRIC/ISS-CAS/JRC (2012). Harmonized World Soil Database (version 1.2). FAO, Rome, Italy and IIASA, Laxenburg, Austria.

FAO (1995). Sustainable dry land cropping in relation to soil to soil productivity FAO Corporate document Repository originated by Agricultural Department M-53 the university $\mathrm{f}$ queens land Gatton, Australia.

FAO (1985). Guidelines: Land Evaluation for Irrigated Agriculture. FAO, Rome.

FAO (2006). Guidelines for soil profile description. Soil Resources, Management and Conservation Service, Land and Water Development Division, $F A O$, Rome

FDRE (The Federal Democratic Republic of Ethiopia) (2011). Growth and Transformation Plan (GTP) 2010/11-2014/15. Ministry of Finance and Economic Development (MoFED), Addis Ababa, Ethiopia.

Fisseha, I (1992). Macro and micronutrients distribution in Ethiopian Vertisols landscapes. $\mathrm{Ph} . \mathrm{D}$. Dissertation submitted to Institute fur Bondenkunde und Standortslehre, University of Hohenheim, Germany. p. 201.
GME (Geological Mapping Ethiopia) (1975). National Geological Map of Ethiopia, Addis Ababa. Ethiopia.

Havlin, JL; Beaton, JD; Tisdale, SL and Nelson, WL (1999). Soil fertility and fertilizers. Prentice Hall, New Jersely pp. 345-355.

Hurni, H (1999). Agro-ecological Belts of Ethiopia. Explanatory notes on three maps at a scale of 1:1,000,000. SCRP Research Report 43. BernAddis Abeba.

Jackson, M.L (1967). Soil chemical analysis. Prentice Hall, Inc., Ebngle wood cliffs, New Jersey. 183$204 \mathrm{pp}$

Jarvis, D and Hodgkin, T (2000). Farmer decision making and genetic diversity linking multidisciplinary research to implementation on-farm. pp. 261-278 in Genes in the field: on - farm conservation of crop diversity Lewis publishers, Boca Raton, FL. USA.

Joachim, H J; Makoi R and Patrick, AN (2008). Selected chemical properties of soil in the traditional irrigation schemes of the Mbulu district, Tanzania. African Journal of Agricultural Research Vol. 3 (5), pp. 348-356.

Khalifa, EM; El-Desoky, MA; Gameh, MA and Faragallah, ME (1996). Status of some micronutrients and their relations to mineral composition of the Nile valley desert interference zone soils, East of Assiut city. Assiut Journal of Agricultural Sciences. 27(3): 107-127.

King, R Band Brachall, CJ (1975). Land systems and soils of the southern Rift Valley, Ethiopia-Land Resource Report Number 5. Ministry of Development, Ethiopia.

Landon, JR (1991). Booker tropical soil manual. A handbook for soil survey and agricultural land evaluation in the tropics and sub tropics. John Wiley and Sons, New York. pp. 94-95.

Lemma, G (1996). Climate Classification of Ethiopia. Meteorological Research Report Series No.3, National Meteorological service Agency of Ethiopia, Addis Ababa.

Mesfin, A (1998). Nature and management of Ethiopian soils. Alemaya University of Agriculture, Ethiopia. pp. 28-35. 
MoA (1995). Land Use Systems and soil conditions of Ethiopia by Land use Study and Rural Technology promotion Department Addis Ababa, Ethiopia, 60p.

Murphy, HF (1968). Reports on fertility status of some soils and other data of Ethiopia. College of Agriculture, Addis Ababa University/ Ethiopia. Experiment Station Bull. No. 44.

NFIU (National Fertilizer Input Unit) (1989). ADD/NFIU joint working paper No. 27 - 31 Ministry of Agriculture, Addis Ababa. Ethiopia.

Oades, JM; Gillman GP; Uehara G; Hue, NV; van Noordwijk, M; Robertson, GP; Wada, K (1989). Interactions of soil organic matter and variablecharge clays. University of Hawaii Press, Honolulu, HI, pp. 69-95.

Ramesh, V; Wani, SP; Rego, TJ; Sharma, KL; Bhattacharyya, T; Sahrawat, KL; Padmaja, KV; GangadharRao, D; Venkateswarlu, B; Vanaja, M; Manna, MC; Srinivas, K and Maruthi V (2007). Chemical Characterization of selected benchmark spots for $\mathrm{C}$ sequestration in the Semi-Arid Tropics, India. Global Theme on Agroecosystem Report no. 32. Andhra Pradesh, India. 106pp.

SAS Institute Inc (2001). For windows has system users guide release version 8.2.

Tan KH (1996). Soil sampling, preparation, and analysis. Marcel Dekker, Inc. New York, USA. pp. 68-78.
Tandon, HLS. Ed (2005). Methods of Analysis of soils, plants, water, fertilizers and organic manure, (ed) FDCO, New Delhi.

Tuma A (2007). Effect of Fruit Based Land Use Systems on Soil Physicochemical Properties: The Case of Smallholders Farming Systems in Gamo Gofa, Southern Ethiopia; MSc thesis, University of Hawassa, Awassa College of Agriculture, Hawassa, Ethiopia. 29068 isricu-t4e2e75e0-001. $115 \mathrm{pp}$.

Uehara, G and Gilman, G (1981). The mineralogy, chemistry and physics of tropical soils with variable charge clays. West view Tropical Agricultural Series, Boulder, Colorado, 4: 170.

Van, LP (1993). Procedures for soil analysis. 4th ed. International Soil Reference and Information Center, the Netherlands. pp. 56-62.

WRB (World Reference Base for Soil resources) (2006). World Soil Resources Report, FAO, Rome. 103 pp.

Yadav, B.K (2011). Micronutrient Status of Soils under Legume Crops in Arid Region of Western Rajasthan, India. Academic Journal of Plant Sciences 4 (3): 94-97. 